\title{
Alterations of muscarinic acetylcholine receptor subtypes in diffuse Lewy body disease: relation to Alzheimer's disease
}

Kazumasa Shiozaki, Eizo Iseki, Haruaki Uchiyama, Yasuhiro Watanabe, Tatsuya Haga, Kimihiko Kameyama, Tomoaki Ikeda, Takayuki Yamamoto, Kenji Kosaka

Department of Psychiatry, Yokohama City University, School of Medicine, 3-9

Fukuura,

Kanazawa-ku,

Yokohama, Kanagawa

236-0004, Japan

K Shiozaki

E Iseki

K Kosaka

Department of Neurosurgery,

Hamamatsu Red Cross

Hospital, 1-5-30

Takabayashi,

Hamamatsu, Shizuoka

430-0907, Japan

H Uchiyama

Department of

Pharmacology,

National Defense

Medical College, 3-2

Namiki, Tokorozawa,

Saitama 359-0042,

Japan

Y Watanabe

Department of

Neurochemistry,

Faculty of Medicine,

University of Tokyo,

7-3-1 Hongo,

Bunkyo-ku, Tokyo

113-0033, Japan

T Haga

K Kameyama

Fukushimura Hospital, 19-14 Yamanaka, Noyori-cho, Toyohashi,

Aichi 441-8124, Japan

T Ikeda

$\mathrm{T}$ Yamamoto

Correspondence to: Dr Kazumasa Shiozaki, Department of Psychiatry, Yokohama City University, 3-9 Fukuura, Kanazawa-ku, Yokohama, Kanagawa 236-0004, Japan. Fax 0081 45783 2540; email:

NBG01035@nifty.ne.jp

Received 11 August 1998 and in final form 17 Febryary 1999

Accepted 23 February 1999
Abstract

Objectives-Dementia associated with Lewy bodies in cortical and subcortical areas is classified as dementia of the nonAlzheimer type and termed diffuse Lewy body disease (DLBD). The generic term "dementia with Lewy bodies (DLB)" was proposed in the international workshop on Lewy body dementia to include the similar disorders presenting Lewy bodies. In DLB, a lower level of choline acetyltransferase (ChAT) activity in the neocortex was found compared with that in Alzheimer's disease. The purpose of the present study was to determine the total amount of muscarinic acetylcholine receptors (mAChRs) and relative proportion of each subtype (m1-m4) of mAChRs in the frontal and temporal cortex of seven DLBD and 11 Alzheimer's disease necropsied brains.

Methods-A [ $\left.{ }^{3} \mathrm{H}\right]$ quinuclidinyl benzilate (QNB) binding assay and an immunoprecipitation assay using subtype-specific antibodies were performed. Each antibody was raised against fusion proteins containing peptides corresponding to the third intracellular (i3) loops of the respective $\mathrm{mAChR}$ subtype.

Results-The total amounts of $\mathrm{mAChRs}$ were significantly lower in the preparations of temporal cortices from DLBD and Alzheimer's disease than in those from dead controls (seven cases). In both diseases, the proportion of the $\mathrm{m} 3$ receptor in the frontal cortex was significantly increased and that of the $\mathrm{m} 4$ receptor in the temporal cortex was significantly decreased compared with the control specimens. The proportions of the $\mathrm{m} 1$ and m2 subtypes were significantly different in the temporal cortex. The proportion of the $\mathbf{m} 1$ receptor was significantly greater in the DLBD brains, whereas that of the $\mathrm{m} 2$ receptor was significantly greater in the Alzheimer's disease brains than in the controls.

Conclusions-The $\mathrm{m} 1$ receptor is the major subtype in the cerebral cortex, and $\mathrm{m} 2$ is known to be present at presynaptic terminals. The higher proportions of $\mathbf{m} 1$ in DLBD and $\mathrm{m} 2$ in Alzheimer's disease suggest that the manner of degeneration in the cholinergic system is different between the diseases. It is hypothesised that a severe depletion of presynaptic cholinergic projective neurons causes the upregulation of $\mathrm{m} 1$ receptor in the temporal cortex in DLBD.

(F Neurol Neurosurg Psychiatry 1999;67:209-213)

Keywords: muscarinic receptor; subtype specific antibody; diffuse lewy body disease; cholinergic deficit

Diffuse Lewy body disease (DLBD) is a recently recognised clinicopathological entity associated with Lewy bodies in cortical and subcortical areas, with distinctive clinical features such as fluctuating cognition and recurrent visual hallucinations. ${ }^{1}$ Similar terminology has been proposed by some researchers, such as Lewy body dementia, senile dementia of Lewy body type, and Lewy body variant of Alzheimer's disease. There is still some confusion regarding the concept of the disease entity. Among these diseases, the neuropathological criteria for the diagnosis of DLBD are the most strict. In the first international workshop on Lewy body dementia in 1995, the generic term "dementia with Lewy bodies" (DLB) was proposed to include the disorders mentioned above. ${ }^{1}$ Dementia with Lewy bodies is not rare $^{2}$; it is reported to be the most common cause of dementia in elderly people after Alzheimer's disease and cerebrovascular dementia..$^{3-5}$ Dementia with Lewy bodies and Alzheimer's disease were reported to account for $20 \%$ and $52 \%$ of dementia in elderly people, respectively. ${ }^{4}$

In Alzheimer's disease, a consistent change is found in the cholinergic neurons. The neocortical cholinergic deficit was recently reported to be more extensive in DLB, and greater neuronal loss in the substantia innominata was found in DLB compared with Alzheimer's disease. ${ }^{6-8}$ Perry et al reported that choline acetyltransferase (ChAT) activity was lower in DLB compared with Alzheimer's disease in temporal and parietal cortices $(10 \%-20 \%$ of controls, compared with $30 \%-70 \%$ of controls). ${ }^{8}$ The 
Table 1 List of patients

\begin{tabular}{lllll}
\hline \multirow{2}{*}{ Patient No } & Age & Sex & Postmortem delay $(h)$ & Cause of death \\
\hline \multicolumn{2}{l}{ Diffuse Lewy body disease (DLBD): } & \\
1 & 80 & $\mathrm{M}$ & 7 & Suffocation \\
2 & 82 & $\mathrm{~F}$ & 4 & Pneumonia \\
3 & 86 & $\mathrm{~F}$ & 6 & Pneumonia \\
4 & 68 & $\mathrm{M}$ & 4 & Pneumonia \\
5 & 74 & $\mathrm{M}$ & 3 & Pneumonia \\
6 & 71 & $\mathrm{M}$ & 3 & Pneumonia \\
7 & 84 & $\mathrm{M}$ & 4 & Heart failure \\
Alzheimer's disease (AD): & & & \\
8 & 73 & $\mathrm{~F}$ & 0.5 & Heart failure \\
9 & 63 & $\mathrm{M}$ & 1.5 & Heart failure \\
10 & 83 & $\mathrm{~F}$ & 2 & Bleeding of the alimentary tract \\
11 & 86 & $\mathrm{M}$ & 5 & Pneumonia \\
12 & 63 & $\mathrm{M}$ & 6 & Heart failure \\
13 & 80 & $\mathrm{M}$ & 1 & Pneumonia \\
14 & 82 & $\mathrm{M}$ & 3 & Heart failure \\
15 & 84 & $\mathrm{~F}$ & 1 & Heart failure \\
16 & 86 & $\mathrm{~F}$ & 5 & Heart failure \\
17 & 76 & $\mathrm{M}$ & 2 & Heart failure \\
18 & 86 & $\mathrm{~F}$ & 2 & Colon cancer \\
Controls & & & & \\
19 & 80 & $\mathrm{M}$ & 0.5 & Pneumonia \\
20 & 85 & $\mathrm{~F}$ & 8 & Pneumonia \\
21 & 91 & $\mathrm{M}$ & 2 & Lung cancer \\
22 & 84 & $\mathrm{M}$ & 12 & Pneumonia \\
23 & 87 & $\mathrm{~F}$ & 3 & Heart failure \\
24 & 89 & $\mathrm{~F}$ & 18 & Heart failure, Sick sinus syndrome \\
25 & 91 & $\mathrm{M}$ & 2 & Uraemia \\
\hline & & & & \\
\hline
\end{tabular}

number of binding sites of muscarinic acetylcholine receptors (mAChRs) was reported to be raised in the neocortex of patients with DLB. $^{9}$

Systematic measurements of $\mathrm{mAChR}$ subtypes in DLBD have never been reported. The genes for five subtypes (m1-m5) of mAChR have been cloned ${ }^{10-15}$ and the five subtypes have distinct distributions in the brain. ${ }^{16}{ }^{17}$ We have raised subtype-specific antisera against the $\mathrm{m} 1$, $\mathrm{m} 2, \mathrm{~m} 3$, and $\mathrm{m} 4$ receptors as described below. In the present study, we estimated the levels of these mAChR subtypes by using the subtype specific antibodies and compared the values for DLBD and Alzheimer's disease.

\section{Materials and methods}

Brain tissue was obtained at necropsy from seven patients with DLBD (mean age 77.9 (SD 6.9 ), range 68-86; mean postmortem delay 4.4 (SD 1.5) hours, range 3-7 hours), 11 patients with Alzheimer's disease (mean age 78.4 (SD 8.7), range 63-86; mean postmortem delay 2.6 (SD 1.9) hours, range 0.5-6 hours) and seven subjects who who had not shown symptoms of either disease (mean age 86.7 (SD 4.0), range 80-91; mean postmortem delay 6.5 (SD 6.5) hours, range $0.5-18$ hours, table 1 ). The dissected brain tissue was immediately frozen in liquid nitrogen, then stored at $-80^{\circ} \mathrm{C}$ until used. All of the patients with DLBD met the following criteria: (1) consensus criteria for the clinical diagnosis of probable and possible "dementia with Lewy bodies"1; and (2) the neuropathological criteria for the diagnosis of DLBD,${ }^{18}$ which are the most strict criteria and demand the presence of more than five or 10 cortical Lewy bodies in the predilection sites in a $\times 100$ visual field in haematoxylin and eosin or ubiquitin immunostained preparations. All of the cases of DLBD were diagnosed as the "common form of diffuse Lewy body disease," because this entity contains the concomitant features of Alzheimer's disease pathology. ${ }^{19}$ All of the cases of Alzheimer's disease met the following inclusion criteria: (1) clinical history of dementia, according to DSM-IV criteria; and (2) consortium to establish a registry in Alzheimer's disease (CERAD) neuropathological criteria for definite Alzheimer's disease. ${ }^{20}$ Four of the seven patients with DLBD had been treated with anticholinergic drugs. None of the patients with Alzheimer's disease had ever been treated with a cholinesterase inhibitor. The diagnosis of "control" was also confirmed since appreciable senile changes were absent in the brains by histopathological analysis. None of them had had a neurological or psychological disorder.

Segments of porcine $(\mathrm{m} 1, \mathrm{~m} 2)$ and rat $(\mathrm{m} 3$, $\mathrm{m} 4) \mathrm{mAChR}$ genes were subcloned into the bacterial expression vector pGEX3X (Pharmacia,Uppsala, Sweden). Recombinant plasmids were confirmed to be in frame by double stranded dideoxy sequencing. The pGEX3X vector encodes the $26 \mathrm{kDa}$ glutathione $\mathrm{S}$-transferase fused to the $\mathrm{N}$-terminus of the putative third intracellular loop (i3 loop) of the $\mathrm{m} 1$ to $\mathrm{m} 4$ receptors. The amino acid sequences expressed as fusion proteins were as follows, $\mathrm{m} 1$ : $\mathrm{Q}(226)-\mathrm{K}(353), \mathrm{m} 2: \mathrm{N}(227)-\mathrm{C}(324), \mathrm{m} 3$ : $\mathrm{S}(302)-\mathrm{Q}(473)$, and $\mathrm{m} 4$ : $\mathrm{P}(247)-\mathrm{Q}$ (352). The differences in amino acids from human $\mathrm{mAChRs}$ were as follows, $\mathrm{m} 1$ : three, $\mathrm{m} 2$ : five, m3: 23, m4: 14. Rabbits were immunised with these fusion proteins by a conventional method for preparing antiserum.

The insect cell line Sf9, which expresses $\mathrm{m} 1$, $\mathrm{m} 2$, and $\mathrm{m} 4$ receptors, was prepared as described. $^{2122}$ Chinese hamster ovary cells expressing $\mathrm{m} 3$ receptors were prepared by the same method used for the preparation of D2 receptor. ${ }^{23}$

Membranes from the cell lines and brain tissue cells were prepared as follows. The brain tissues were suspended and homogenised in medium A (10 $\mathrm{mM}$ potassium phosphate buffer ( $\mathrm{pH}$ 7.0), $1 \mathrm{mM}$ EDTA, and $0.32 \mathrm{M}$ sucrose) containing $1 \mathrm{mM}$ benzamidine, 0.5 $\mathrm{mM}$ phenylmethyl sulphanyl fluoride, and 5 $\mu \mathrm{g} / \mathrm{ml}$ pepstatin A. After centrifugation at 1000 $g$ for 10 minutes, supernatants were collected and centrifuged at $20000 \mathrm{~g}$ for 30 minutes. The pellets were suspended in medium B (the same as medium A except for the omission of sucrose) and centrifuged again at $20000 \mathrm{~g}$ for 30 minutes. Finally, the pellets were suspended in $10 \mathrm{ml}$ medium $\mathrm{B} / \mathrm{g}$ original tissue.

The amounts of total mAChRs were estimated as the specific binding sites of $\left[{ }^{3} \mathrm{H}\right] \mathrm{QNB}$ in membrane preparations. The specific binding was defined as the difference between the total and non-specific bindings, which were estimated by incubation with $\left[{ }^{3} \mathrm{H}\right] \mathrm{QNB}(1.5$ $\mathrm{nM}$ ) for 90 minutes at $30^{\circ} \mathrm{C}$ in the absence and presence of $1 \mu \mathrm{M}$ atropine, respectively. The amounts of proteins were measured by using an assay kit from Bio-Rad (Hercules, CA, USA) and bovine serum albumin as a standard. The specific $\left[{ }^{3} \mathrm{H}\right] \mathrm{QNB}$ binding sites for membrane preparations of each cell line were estimated to be $15,15,7.0$, and $5.0 \mathrm{pmol} / \mathrm{mg}$ protein for the $\mathrm{m} 1, \mathrm{~m} 2, \mathrm{~m} 3$, and $\mathrm{m} 4$ receptors, respectively. 
Table 2 Immunoprecipitation of muscarinic acetylcholine receptor subtypes using subtype specific antiserum

\begin{tabular}{|c|c|c|c|c|c|}
\hline \multirow[b]{2}{*}{ Disease } & \multirow{2}{*}{$\begin{array}{l}{\left[{ }^{3} H\right] Q N B \text { bound }} \\
\text { (fmollmg) }\end{array}$} & \multicolumn{4}{|c|}{ Proportions of precipitated $m A C h R$} \\
\hline & & $m 1(\%)$ & $m 2(\%)$ & $m 3(\%)$ & $m 4(\%)$ \\
\hline \multicolumn{6}{|l|}{ Frontal cortex } \\
\hline Controls $(n=7)$ & $1289(139)$ & 52.0 & 9.1 & 6.9 & 10.0 \\
\hline $\operatorname{DLBD}(n=6)$ & $1128(262) \ddagger$ & 50.5 & 8.4 & $9.8^{\star}$ & 9.2 \\
\hline $\mathrm{AD}(\mathrm{n}=11)$ & $1407(181)$ & 51.0 & 9.4 & $9.6^{\star \star}$ & 9.4 \\
\hline \multicolumn{6}{|l|}{ Temporal cortex } \\
\hline Controls (n=7) & $1934(188)$ & 53.2 & 9.1 & 7.3 & 10.6 \\
\hline $\operatorname{DLBD}(\mathrm{n}=7)$ & $1120(95)^{\star \star} \dagger$ & $58.1^{\star} \ddagger$ & $8.5 \ddagger$ & 8.2 & $6.8^{\star \star}$ \\
\hline $\mathrm{AD}(\mathrm{n}=11)$ & $1371(298)^{\star \star}$ & 52.1 & $11.6^{\star \star}$ & 9.3 & $7.6^{\star \star}$ \\
\hline
\end{tabular}

Data are mean (SD) data from a representative experiment. The density of mAChR was estimated as specific binding with $\left[{ }^{3} \mathrm{H}\right] \mathrm{QNB}$, and ranged from 800 to $2200 \mathrm{fmol} / \mathrm{mg}$ membrane protein. The proportions of specifically precipitated $\mathrm{mAChR}$ subtypes were estimated as the differences in the amounts of bound $\left[{ }^{3} \mathrm{H}\right] \mathrm{QNB}$ precipitated with specific antiserum and those precipitated with non-immune serum.

${ }^{\star} \mathrm{p}<0.05 ;{ }^{\star \star} \mathrm{p}<0.01 v$ controls; $\uparrow \mathrm{p}<0.05 ; \ddagger<0.01 v \mathrm{AD}$.

Membrane preparations from postmortem human brains were incubated in KPB $(10 \mathrm{mM}$ potassium phosphate buffer ( $\mathrm{pH} 7.0), 1.0 \mathrm{mM}$ EDTA, $0.1 \mathrm{M} \mathrm{NaCl}$ ) at $30^{\circ} \mathrm{C}$ for 90 minutes with $\left[{ }^{3} \mathrm{H}\right] \mathrm{QNB}(2.3 \mathrm{nM})$ and centrifuged at $15000 \mathrm{~g}$ for 15 minutes to take off free $\left[{ }^{3} \mathrm{H}\right] \mathrm{QNB}$ from the membrane preparation. The labelled membrane was washed in KPB containing $0.1 \%$ sodium cholate, and then $\mathrm{mAChR}$ was solubilised in KPB containing $1.0 \%$ digitonin and $0.1 \%$ sodium cholate for at least 4 hours at $4^{\circ} \mathrm{C}$. The solubilised $\mathrm{mAChR}$ was collected as a supernatant from centrifugation at $15000 \mathrm{~g}$ for 20 minutes at $4^{\circ} \mathrm{C}$. The proportions of solubilised $\left[{ }^{3} \mathrm{H}\right] \mathrm{QNB}$ labelled receptors were $70 \%-95 \%$ of the $\left[{ }^{3} \mathrm{H}\right] \mathrm{QNB}$ binding sites in each membrane preparation. The supernatant $(40 \mu \mathrm{l})$ containing 20-100 fmol $\left[{ }^{3} \mathrm{H}\right] \mathrm{QNB}-$ labelled receptors was mixed with $4 \mu \mathrm{l}$ antiserum before incubation at $4^{\circ} \mathrm{C}$ for at least 4 hours. After addition of $20 \mu \mathrm{l}$ Pansorbin (Calbiochem,La Jolla, CA, USA), the mixture was incubated at $4^{\circ} \mathrm{C}$ with rotation for 1 hour and then precipitated at $15000 \mathrm{~g}$ for 10 minutes. The Pansorbin deposit was washed with $200 \mu \mathrm{KPB}$ and pelleted again at $15000 \mathrm{~g}$ for 10 minutes. The amount of $\left[{ }^{3} \mathrm{H}\right] \mathrm{QNB}$ in the pellet was determined by liquid scintillation counting. The percentage of immunoprecipitation was calculated by dividing the amount of $\left[{ }^{3} \mathrm{H}\right] \mathrm{QNB}$ count in the Pansorbin pellet by the whole count in the total supernatant and Pansorbin pellet.

A one way analysis of variance (ANOVA) followed by a least significant difference (LSD) test was used to compare the values of total QNB binding and the proportions of subtypes (m1 to $\mathrm{m} 4)$. Statistical evaluations were performed with the SPSS package.

\section{Results}

The specificity of antisera raised against GST fusion proteins incorporating the i3 loops was tested by the immunoprecipitation of $\mathrm{MAChR}$ subtypes. The results indicated that each of the antisera specifically recognised and precipitated only one of the $\mathrm{m} 1-\mathrm{m} 4$ receptors (figure).

The amounts of $\left[{ }^{3} \mathrm{H}\right] \mathrm{QNB}$ binding sites in membrane preparations ranged from 0.8 to 1.8 $\mathrm{pmol} / \mathrm{mg}$ protein (frontal cortex) and from 0.8 to $1.9 \mathrm{pmol} / \mathrm{mg}$ protein (temporal cortex). In the temporal cortex, the $\left[{ }^{3} \mathrm{H}\right] \mathrm{QNB}$ binding sites of the DLBD and Alzheimer's disease tissues were significantly lower than those of the control tissue. The $\left[{ }^{3} \mathrm{H}\right] \mathrm{QNB}$ binding sites in DLBD were significantly lower than those in Alzheimer's disease. In the frontal cortex, there were no significant differences in $\left[{ }^{3} \mathrm{H}\right] \mathrm{QNB}$ binding sites comparing DLBD or Alzheimer's disease with controls, whereas these binding sites were significantly lower in DLBD than in Alzheimer's disease.

Membrane preparations from the brains were used for precipitation with each of the antisera against $\mathrm{m} 1-\mathrm{m} 4$ receptors. The proportions of $\left[{ }^{3} \mathrm{H}\right] \mathrm{QNB}-$ receptor complex precipitated with each of the antisera in solubilised $\left[{ }^{3} \mathrm{H}\right] \mathrm{QNB}-$ receptor complex were estimated and are summarised in table 2 . The proportions of $\left[{ }^{3} \mathrm{H}\right] \mathrm{QNB}-$ receptor complex precipitated with the antiserum against $\mathrm{m} 1, \mathrm{~m} 2, \mathrm{~m} 3$, and $\mathrm{m} 4$ receptors were estimated to be $44.4 \%$ $60.6 \%, 6.4 \%-15.8 \%, 3.3 \%-14.8 \%$, and $4.7 \%-$ $14.7 \%$, respectively. In the frontal cortex, the proportion of $\left[{ }^{3} \mathrm{H}\right] \mathrm{QNB}-$ receptor complex precipitated with anti-m3 antibodies was significantly higher in both DLBD and Alzheimer's disease than in controls. In the temporal cortex, the $\left[{ }^{3} \mathrm{H}\right] \mathrm{QNB}-$ receptor complex precipitated with anti-m4 antibodies was significantly lower in DLBD and Alzheimer's disease than in controls. By contrast, $\left[{ }^{3} \mathrm{H}\right] \mathrm{QNB}-$ receptor complex precipitated with anti-m1 antibodies was significantly higher in DLBD than in controls, whereas the precipitate by $\mathrm{m} 2$ antiserum was significantly higher in Alzheimer's disease than in controls. The level of $\mathrm{m} 1$ in DLBD was significantly higher than that in Alzheimer's disease, whereas the level of $\mathrm{m} 2$ in DLBD was significantly lower than that in Alzheimer's disease.

\section{Discussion}

Our results show common and different characteristics of mAChR in Alzheimer's disease and DLBD. The saturated bindings of $\left[{ }^{3} \mathrm{H}\right] \mathrm{QNB}$ were lower in DLBD and Alzheimer's disease tissues than in control tissues in the temporal area. Perry et al reported that ChAT activity was seriously reduced in temporal and parietal cortices whereas low affinity $\mathrm{mAChR}$ binding was significantly increased in DLB but not in Alzheimer's disease. ${ }^{9}{ }^{24}$ We do not know the reason for the differences in the total binding sites of $\mathrm{mAChR}$ among the tissues examined here. The major finding of the present study was that the total binding sites of $\mathrm{mAChR}$ in DLBD and Alzheimer's disease were decreased in the temporal area, but not in the frontal area. We suspect that the depletion of the cholinergic system is more severe in the temporal area than in the frontal area.

It is not possible to determine the absolute proportion of $\mathrm{m} 1$ to $\mathrm{m} 4$ receptors strictly by our method of immunoprecipitation, because the efficiencies of solubilisation or precipitation may vary among these receptors. As shown in the figure, the efficiency of immunoprecipitation of $\mathrm{m} 3$ receptor was lower than that of the other subtypes. $\mathrm{m} 3$ Receptor was expressed in Chinese hamster ovary cells, whereas $\mathrm{m} 1, \mathrm{~m} 2$, 


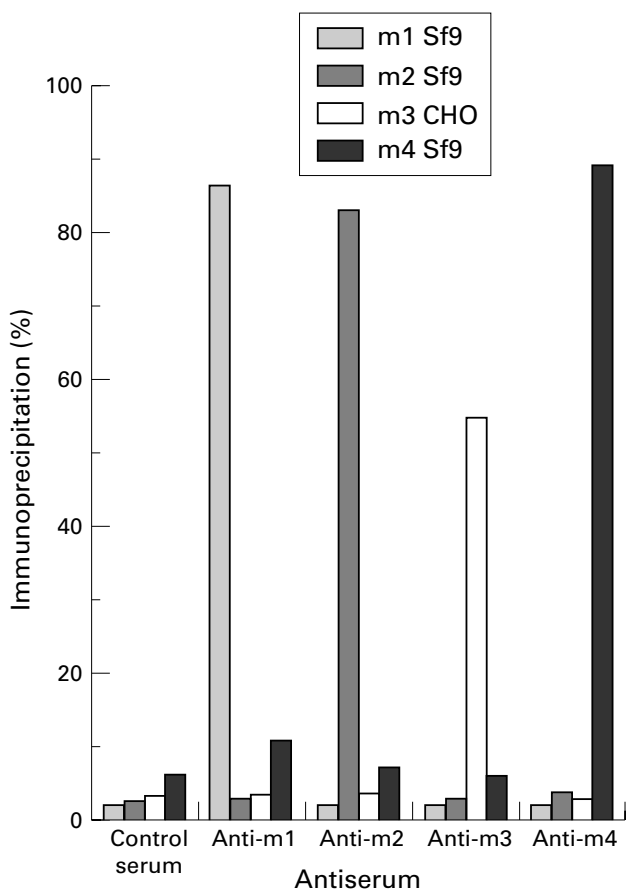

Each antiserum can immunoprecipitate a single cloned $m A C h R$ subtype ( $m 1-m 4)$ in a subtype specific manner. The $m 1, m 2$, and $m 4$ receptors were expressed in Sf9 cells, and the membrane preparations were labelled with $\left.{ }^{3} \mathrm{H}\right] Q N B$ and then solubilised with $1 \%$ digitonin and $0.1 \%$ sodium cholate. The $m 3$ receptors were treated in the same way except that they were expressed in Chinese hamster ovary cells instead of Sf9 cells, because the $m 3$ receptors expressed in Sf9 cells were reported not to be solubilised with digitonin. The $m 3$ receptor in Chinese hamster ovary cells could be solubilised for precipitation. Solubilised receptors were precipitated with antisera. Roughly 85, 82, 58, and 90\% of solubilised $m 1, m 2, m 3$, and $m 4$ receptors, respectively, were precipitated with the specific antiserum, whereas less than $10 \%$ of solubilised receptors were precipitated with non-immune serum (control serum) or antiserum against other subtypes.

and $\mathrm{m} 4$ were expressed in Sf9 cells. The solubility of receptors may be changed when the composition of the cell membrane is different. We were able to compare the relative changes of mAChR subtypes in Alzheimer's disease, DLBD, and controls because the efficiencies of solubilisation and immunoprecipitation are thought to be essentially the same among these states. We can only discuss alterations of mAChR subtypes in the comparison of DLBD, Alzheimer's disease, and controls.

In the frontal cortex, the levels of the $\mathrm{m} 3$ subtype in the present cases of DLBD and Alzheimer's disease were higher than in the control cases. In the temporal cortex, the level of the m4 subtype in DLBD and Alzheimer's disease was lower than that in controls. Flynn et al reported increases of immunoprecipitated $\mathrm{m} 4$ receptor protein in frontal, temporal, and parietal cortices of Alzheimer's disease. ${ }^{25} \mathrm{We}$ cannot explain the opposite results of $\mathrm{m} 4$ subtypes. We suspect that the increase of $\mathrm{m} 3$ in the frontal cortex and the decrease of $\mathrm{m} 4$ in the temporal cortex are the results of cholinergic destruction, which is common in both types of degenerative dementia.

In the temporal cortex, the differences were found in the $\mathrm{m} 1$ and $\mathrm{m} 2$ receptor levels between DLBD and Alzheimer's disease. The $\mathrm{m} 1$ level was higher in DLBD than in controls, whereas the $\mathrm{m} 2$ level was higher in Alzheimer's disease than in controls. Comparing the two disease states, $\mathrm{m} 1$ receptor was somewhat higher in DLBD and $\mathrm{m} 2$ was higher in Alzheimer's disease. The $\mathrm{m} 1$ receptor was shown to be the most abundant subtype present in the cerebral cortices and hippocampus of the human brain by immunoprecipitation assay. ${ }^{25}$ The $\mathrm{m} 2$ receptor has been shown to exist at the presynapses of the cholinergic system, in an examination of the presence of m2 mRNA. ${ }^{26}$ A pharmacological properties analysis $^{27}$ and electron microscopic studies ${ }^{28-30}$ showed that $\mathrm{m} 2$ is located at the presynaptic termini of the cholinergic system.

The $\mathrm{mAChR}$ binding sites in DLBD and Alzheimer's disease were decreased in the temporal cortex more than in controls, and in DLBD the $\mathrm{mAChR}$ binding sites were significantly lower than in Alzheimer's disease. The ChAT activity was decreased in both diseases more than in controls, ${ }^{68}$ and temporal ChAT activity was significantly lower in DLBD than in Alzheimer's disease. ${ }^{8}$ The cholinergic deficit is considered to be more severe in DLBD than in Alzheimer's disease. We suspect that the mechanism of cholinergic depletion in DLBD is different from that in Alzheimer's disease. The higher level of $\mathrm{m} 1$ in the present cases of DLBD suggests the possibility that $\mathrm{m} 1$ (the major subtype of postsynaptic mAChR) is preserved or upregulated in this disease. We suspect that the destruction of cholinergic projection neurons precedes the loss of cholinoreceptive neurons in the temporal area in DLBD; this possibility seems to be in good agreement with the reduction of ChAT activity in DLBD reported previously. ${ }^{4}$ On the other hand, the immunoprecipitated $\mathrm{m} 2$ levels were higher in the present cases of Alzheimer's disease than in the controls and cases of DLBD. We speculate that the loss of cholinoreceptive neurons precedes the loss of presynaptic cholinergic projection neurons in Alzheimer's disease. The higher $\mathrm{m} 2$ level in Alzheimer's disease suggests that the presynaptic $\mathrm{m} 2$ receptors are preserved or upregulated in this disease.

Our present findings provide the first description of the alteration of molecular subtypes of $\mathrm{mAChR}$ in DLBD and its difference from Alzheimer's disease. Our findings suggest differences in cholinergic deficits between DLBD and Alzheimer's disease. In recent trials of cholinergic replacement therapies, DLBD was indicated to be an entity which is more responsive to cholinesterase inhibitor (tacrine) compared to Alzheimer's disease. ${ }^{5132}$ We suspect that a severe deficit of cholinergic projections in conjunction with the relative preservation of $\mathrm{m} 1$ in DLBD at the temporal cortex is one of the reasons for the good response to tacrine.

1 McKeith IG, Galasko D, Kosaka K, et al. Consensus guidelines for the clinical and pathological diagnosis of dementia with Lewy bodies (DLB). Neurology 1996;47:1113-24.

2 Byrne EJ, Lennox G, Lowe J, et al. Diffuse Lewy body disease: clinical features in 15 cases. $\mathcal{F}$ Neurol Neurosurg Psychiatry 1989;52:709-17. 
3 Dickson DW, Crystal H, Mattiace LA, et al. Diffuse Lewy body disease: light and electron microscopic immunocytochemistry

4 Perry EK, McKeith I, Thompson P, et al. Topography, extent, and clinical relevance of neurochemical deficits in dementia of Lewy body type, Parkinson's disease, and Alzheimer's disease. Ann N Y Acad Sci 1991;640:197-202.

5 Liberini P, Valerio A, Memo M, et al. Lewy-body dementia and responsiveness to cholinesterase inhibitors: a paradigm for heterogeneity of Alzheimer's disease? Trends Pharmaco Sci 1996;17:155-60

6 Dickson DW, Davies P, Mayeux R, et al. Diffuse Lewy body disease. Neuropathological and biochemical studies of six patients. Acta Neuropathologica 1987;75:8-15.

7 Hansen L, Salmon D, Galasko D, et al. The Lewy body variant of Alzheimer's disease: a clinical and pathologic entity [comments]. Neurology 1990;40:1-8.

[comments]. Neurology 1990;40:1-8.
8 Perry EK, Haroutunian V, Davis KL, et al. Neocortical Perry EK, Haroutunian V, Davis KL, et al. Neocortical cholinergic activities differentiate Lewy body dementia 9 .

9 Perry EK, Smith CJ, Court JA, et al. Cholinergic nicotinic and muscarinic receptors in dementia of Alzheimer Parkinson and Lewy body types. $\mathcal{F}$ Neural Transm Park Dis Dement Sect 1990;2:149-58.

10 Bonner TI, Buckley NJ, Young AC, et al. Identification of a family of muscarinic acetylcholine receptor genes [published erratum appears in Science 1987;237:237]. Science 1987;237:527-32.

11 Bonner TI, Young AC, Brann MR, et al. Cloning and expression of the human and rat $\mathrm{m} 5$ muscarinic acetylcholine receptor genes. Neuron 1988;1:403-10.

12 Kubo T, Fukuda K, Mikami A, et al. Cloning, sequencing and expression of complementary DNA encoding the muscarinic acetylcholine receptor. Nature 1986;323:411-6.

13 Kubo T, Maeda A, Sugimoto K, et al. Primary structure of porcine cardiac muscarinic acetylcholine receptor deduced
from the cDNA sequence. FEBS Lett 1986;209:367-72.

14 Peralta EG, Ashkenazi A, Winslow JW, et al. Distinct primary structures, ligand-binding properties and tissuespecific expression of four human m
receptors. EMBO $\mathcal{7} 1987 ; 6: 3923-9$.

15 Peralta EG, Winslow JW, Peterson GL, et al. Primary structure and biochemical properties of an M2 muscarinic receptor. Science 1987;236:600-5.

16 Hulme EC, Birdsall NJ, Buckley NJ. Muscarinic receptor subtypes. Annu Rev Pharmacol Toxicol 1990;30:633-73.

17 Levey AI, Kitt CA, Simonds WF, et al. Identification and localization of muscarinic acetylcholine receptor proteins in brain with subtype-specific antibodies. I Neurosci 1991;11:3218-26.
18 Kosaka K. Diffuse Lewy body disease. Intern Med 1998;37: 6-10.

19 Kosaka K. Diffuse Lewy body disease in Japan. 7 Neurol 1990;237:197-204.

20 Mirra SS, Heyman A, McKeel D, et al. The Consortium to Establish a Registry for Alzheimer's Disease (CERAD). Neurology 1991;41:479-86.

21 Parker EM, Kameyama K, Higashijima T, et al. Reconstitutively active $G$ protein-coupled receptors purified from baculovirus-infected insect cells. F Biol Chem 1991;266: 519-27.

22 Rinken A, Kameyama K, Haga T, et al. Solubilization of muscarinic receptor subtypes from baculovirus infected Sf9 insect cells. Biochem Pharmacol 1994;48:1245-51.

23 Itokawa $M$, Toru $M$, Ito $K$, et al. Sequestration of the short and long isoforms of dopamine D2 receptors expressed in Chinese hamster ovary cells. Mol Pharmacol 1996;49:5606.

24 Perry EK, Irving D, Kerwin JM, et al. Cholinergic transmitter and neurotrophic activities in Lewy body dementia: similarity to Parkinson's and distinction from Alzheimer disease. Alzheimer Dis Assoc Disord 1993;7:69-79.

25 Flynn DD, Ferrari DG, Mash DC, et al. Differential regulation of molecular subtypes of muscarinic receptors in Alzheimer's disease. $\mathcal{7}$ Neurochem 1995;64:1888-91.

26 Vilaro MT, Wiederhold KH, Palacios JM, et al. Muscarinic M2 receptor mRNA expression and receptor binding in cholinergic and non-cholinergic cells in the rat brain: a correlative study using in situ hybridization histochemistry and relative study using in situ hybridization histochemistry a
receptor autoradiography. Neuroscience 1992;47:367-93.

27 Feuerstein TJ, Lehmann J, Sauermann W, et al. The autoinhibitory feedback control of acetylcholine release in human neocortex tissue. Brain Res 1992;572:64-71.

28 Hersch SM, Gutekunst CA, Rees HD, et al. Distribution of $\mathrm{m} 1-\mathrm{m} 4$ muscarinic receptor proteins in the rat striatum: light and electron microscopic immunocytochemistry using subtype-specific antibodies. F Neurosci 1994:14: 3351-63.

29 Levey AI, Edmunds SM, Hersch SM, et al. Light and electron microscopic study of $\mathrm{m} 2$ muscarinic acetylcholine
receptor in the basal forebrain of the rat. 7 Comp Neurol receptor in the basal

30 Levey AI, Edmunds SM, Koliatsos V, et al. Expression of $\mathrm{m} 1-\mathrm{m} 4$ muscarinic acetylcholine receptor proteins in rat hippocampus and regulation by cholinergic innervation. $\mathcal{f}$ Neurosci 1995;15:4077-92.

31 Wilcock GK, Scott M, Pearsall T. Long-term use of tacrine [letter]. Lancet 1994;343:544

32 Levy R, Eagger S, Griffiths M, et al. Lewy bodies and response to tacrine in Alzheimer's disease [letter, comments]. Lancet 1994;343:176. 